\title{
SEPARATISM TODAY: THE GEOPOLITICALLY SIGNIFICANT CASE OF CATALONIA
}

\author{
Anamaria MANOLE, \\ BA student in Security Studies, Faculty of Political Science, University of Bucharest, \\ Romania. \\ E-mail: aem.manole@gmail.com
}

\begin{abstract}
Catalonia's national identity has its roots in the Middle Ages and Early Modern Times. In the $19^{\text {th }}$ century, the Catalonian search for independence was encouraged by romantic and revolutionary concepts spread across Europe. After the First World War, we can notice a significant increase of political actions as regards the Catalonian nationalists-separatists, including violent episodes and riots in main cities. As for the contemporary period, the financial crisis in 2007-2008 acted as a new booster for nationalist-separatist ideas leading eventually to referendums in 2009 and also in 2017. The present study is exploring in a historical register the process of Catalonian's independence. In doing so, I intend to identify and examine the Catalan's main reasons in claiming complete political independence. The study tackles particularly recent interviews presenting opinions of several Catalonian citizens, some of them with political or administrative responsibilities, concerning regional independence and its potential consequences.
\end{abstract}

Keywords: Catalan's national identity; political independence/autonomy; politico-territorial controversy; contemporary conflicts.

\section{Introduction}

The kingdom of Spain is a European state in south-western region of the continent, well known for its exports of fruits, vegetables, olive oil, wine, medication, etc. across the globe. Since the fourth decade of the $20^{\text {th }}$ century tourism, industry and agriculture became the main pillars of the country's economy.

It is one of the oldest European countries, which encompassed all of its present-day territory by 1512 . The state-building occurred under monarchical government prior to the rise of nationalism, and this could help explain the continuing salience of territorial identities and the periodic willingness of the political centre to permit territorial elites to retain some prior privileges and separate laws (Henders, 2010, 50).

The construction of national identity in terms of ethnicity has been ruled out as in most European countries. Even so, there is not really just one national image with which the Spaniards identify themselves; there are many different ideologically and territorially based conceptions of the country (Solis, 2003, 11).

Nowadays, Spain is a parliamentary democracy and constitutional monarchy, even it has experienced- and still experiences, as we'll see along this study- conflicts over the territorial distribution of political authority, due to asymmetries of history, language, identity, socioeconomic factors and geography.

In this paper, my intention is to do research through the historical course of the $20^{\text {th }}$ and $21^{\text {st }}$ century regarding the rising of nationalism in the region of Catalonia. Assuming that I will succeed in doing so, I will also try to find the main reasons which led the Catalans to claim for 
STRATEGIES XXI International Scientific Conference

The Complex and Dynamic Nature of the Security Environment

complete political independence. My research is focused on three directions of analysis, as it follows: 1. Historical background of Catalanism in the $20^{\text {th }}$ century; 2 . The nationalist movements of Catalans in the $21^{\text {st }}$ century; 3 . Opinions of several Catalonian citizens regarding the independence of their region.

\section{Historical background of Catalanism in the $20^{\text {th }}$ century}

Back in the $18^{\text {th }}$ and the $19^{\text {th }}$ centuries, territorial identity claims along with conflicts over the secularization and class interests were politically salient in Spain. In the late $19^{\text {th }}$ century, the central state of Spain had been weakened by ideological conflicts, besides the loss of the Spanish Empire and economic stagnation (Henders, 2010, 51). This might be how the first explicitly Catalan nationalist program took place: they wanted to distance themselves from the Spanish problems and by this ground they decided to create a new ontology rooted in their culture, language and worldview.

In 1914 it was established the Catalan Regional Government (Mancomunitat de Catalunya) based on the so-called Bases de Manresa., considered as the "birth certificate of political Catalanism", at least that of conservative roots. Among its forecasts, the third base says that the Catalan language will be the only one that can be used officially in Catalonia and in the relations of this region with the central power (Foguet, Boreu, 1966, 272). In the fourth base, we remark that Only Catalans, both those by birth and those who are by naturalization, may hold public office in Catalonia, including government and administrative positions that depend on the central power (Foguet, Boreu, 1966, 272). Also, in the sixth base it is said that Catalonia will be the only sovereign of its internal government, therefore it will freely dictate its organic laws; It will take care of its civil, criminal, commercial, administrative and procedural legislation; establishment and collection of taxes (...) (Foguet, Boreu, 1966, 273). By this point, Catalans managed to accomplish few of their aspirations for decades.

Until the mid-1920's Catalanism was a middle-class conservative movement which carried out a policy of cooperation with the Central Government - as example, the actions of Lliga Regionalista, founded in 1901, which pleaded for an ambitious project involving both Catalonia and Spanish State-. Since 1923, Primo de Rivera - who served as a prime minister of Spain - was struggling to abolish the catalan official institutions, like the Mancomunitat de Catalunya - deliberative assembly that advocated the federalization of Spain. The dictatorship managed to disband and outlaw it in 1925. Although this assembly had only administrative functions, it represented the first recognition of Catalan identity and territorial unity by Spaniards since 1714, being also responsible for the creation of many public institutions in health, culture, technical education and science and notably for the support of the Catalan language.

In 1936, Spanish Civil war broke out as an outcome of polarization of Spanish life and politics that had developed over previous decades: on one side, the Nationalists - were most Roman Catholics, important elements of the military, most landowners, and many businessmen -, and on the other side, Republicans - were urban workers, most agricultural labourers, and many of the educated middle class - (Editors of Encyclopaedia Britannica, 2021). Also in that period the Catalan statute was implemented, establishing the Generalitat made up of a Catalan parliament, president and executive council (Henders, 2010, 51). In the same year, Francisco Franco Bahamonde was appointed as Generalissimo (a military rank of the highest degree) and Head of State, also holding the function of leader of Bando nacional (Nationalist faction). By consolidating all nationalist parties into a one-party state (FET y de las JONS), he succeeded in declaring Nationalists victory in 1939, thus and so his dictatorship was extended over Spain through a period of repression of political opponents. After the war, the Franco regime 
abrogated the autonomy statutes, making the suppression of public expressions of territorial identity a pillar of its political program. Until 1943, the regime banned Catalan language from public use, destroyed their books and patriotic monuments. He prohibited university classes and institutions dedicated to Catalan culture, banned the Catalan flag, anthem, and national dance (Henders, 2010, 51). Many individuals who resisted were fired, fined, jailed or forced into exile. (Conversi, 1997, Ch5, 155-158). Culturally, Franco's regime imposed on the country an official version of Spain and Spainishness based on uniformity and homogeneity, seeking the root out all traces of cultural and ideological differences (Solis, 2003, 21). In later years, the regime allowed public expressions of Catalan identity in only specified controlled situations (Henders, 2010, 51). Throughout these harshest years of the dictatorship in Spain, the fight for Catalan identity recognition was a difficult one, as it was the struggle for democracy. Furthermore, this period of repression convinced Catalan political elites that democratization required the recognition of territorial-cultural difference and that territorial self-rule would not be restored without democratization (Henders, 2010, 55).

After Franco's death in 1975, the tension about the identity problem gathered new momentum with the development of the State through the setting in progress of a democratic Constitution. So on, after the ending of the dictatorship, with the whole country united behind one democratic objective, a plurality of viewpoints re-emerged. The distribution of territorial and political authority gave birth to antagonistic visions over the new democratic state. One of them was referring to the unitary nature, centralization and homogeneity along the lines of the modern state and citizen model, while the other one cantered around the open way for a federalized, decentralized and even asymmetrically organised Spain. In this regard, Art. 1 of the Constitution established a single sovereignty, residing in the Spanish people, from which the powers of the State emanate, emphasizing the indissoluble unity of the Spanish nation, common and indivisible patria of all Spaniards (Agencia Estatal Boletín Oficial del Estado, 1978). By contrast, Art. 2 recognized and guaranteed the right to autonomy of the nationalities and regions of which it is comprised (Agencia Estatal Boletín Oficial del Estado, 1978). Thus, by speaking of nationalities and regions, the contradictions encountered in the first articles of the Constitution implied differences amongst Spain's territorial communities and individual citizens.

Spanish political elites wanted to secure a democratic transition partly by agreeing to give special status to Catalonia who had an active nationalist movement claiming the territory and a distinct identity due to its language, which was maybe one the most important aspects that have been preserved even in the toughest times along the history. By the time of Franco's death, about 78 percent of Catalonia residents still claimed to speak Catalan. As I said before, the post-Franco Spanish Constitution allowed groups of historical provinces across the country to form Autonomous Communities with organic laws (Statutes of Autonomy). The Catalan AC was established with the most expensive competencies possible by means of the first two articles of the Constitution mentioned before, enjoying a high level of self-rule through its institutions (a parliament, government and Premier) known collectively as the Generalitat (Real Instituto Elcano, 2015, 18). The Community has been ethnolinguistically diverse, considering the fact that in 1981 about 35 percent of its 5.1 million residents were born outside Catalonia, which meant that those individuals had identities different from Catalan natives. Therefore, their interests didn't interspersed with the native Catalans; for example, their economic concerns were about their low-status derived from lower-paid occupations, while Catalans were concerned about economic development across their region after the Franco era (Henders, 2010, $58-86)$.

Only two weeks after more than one million Catalans participated in the Diada (Catalan's National Day) in 1977, they succeeded in restoring the Generalitat, and two years later the Cortes (Spanish parliament) approved their autonomy statute. Subsequently, in the 
STRATEGIES XXI International Scientific Conference

The Complex and Dynamic Nature of the Security Environment

eighth decade of the $20^{\text {th }}$ century, few of the long-term targets of the historical region of Catalonia were accomplished: The Spanish Constitution recognized Catalan as a regional language co-official with Castilian (Generalitat de Catalunya, 2019), the central government had less control over the regional government, Catalonia had its own largely autonomous police forces and more autonomy in matters of tax and fiscal autonomy. So the Catalan special status arrangement contributed to the successful transition to a democratic state. Afterwards, controversy surrounding the autonomy statute had tested the stability of the arrangement, for its provisions appear to push Spain towards greater levels of political decentralization because of the recognition of multiple nations, and this fact was about to challenge the modern territorial state and citizenship model (Moreno Fernandez, 1986, 157-170).

\section{The nationalist-separatist movements of Catalans in the $21^{\text {st }}$ century}

In order to find an explanation for the nationalist-separatists movements in the contemporary period, we should take a look at how the political sphere influenced the emergence of manifestations. According to Michael Keating (1994, 39-59), there are three explanations of the emergence of nationalism in the region of Catalonia: first of them is based on an ethnic dimension, which has a stronger presence through last centuries; the second one is based on the will of the people; the third one explains the emergence of nationalism as an instrument of a political elite seeking to create a state through a nationalistic appeal. Even if there is a long story behind the construction of Catalan's inclusive nationalism, its foundation does not seem like being created by just one of the three explanations, but strongly developed by political elites together with the citizen's cravings and their feeling of belonging to a distinct nation.

I will focus, as I consider it is one of the most important research areas for this paper, on the Catalan territorial politics. This politics have been dominated by political parties representing various intensities and varieties of nationalism and a range of ideological orientations. From 1980 until 2003, the region was governed by Center-Right Christian Democratic (Unió del Centre i la Democràcia Cristiana de Catalunya, UCiDCC) and moderate nationalist coalitions led by Convergence and Union (Convergència i Unió, CiU) - a party wellknown for his influence in reference to the independence of Catalonia, by its leader Jordi Pujol, who used to defend the notion of Catalonia as a nation within Spain - (Carrera, 2014, 77). In 2003, the CiU lost control to the Socialist Party of Catalonia (Partit dels Socialistes de Catalunya, PSC-PSOE), which formed a coalition with the independence-supporting Catalan Republican left (Esquerra Republicana de Catalunya, ERC) and with Green-Initiative for Catalonia United (Iniciativa per Catalunya Verds, ICV). Even so, CiU remained the party with the most seats in the Catalan parliament.

In 2004, the elections changed the course of politics, with Luis Rodriguez Zapatero as the leader of the party who took over the government - Spanish Socialist Workers Party (Partido Socialista Obrero Español, PSOE). After this, Catalonia's Tripartit coalition announced the plan of elaborating a new Statute for their region, which seemed to be supported by Zapatero; the statute was asking, among other things, for Catalonia to be recognised as a political nation, for a new economic agreement system and for the establishment that the Generalitat will collect all of the state taxes from the first year and will have regulatory capacity over them (El pais, 2005). In 2005 a civic platform of more than 700 organizations of any kind was created in Barcelona with the name Plataforma pel dret a decidir (Civic Platform for the right to decide); its first major event demonstrations took place in 2006 (Vilaregut Sáez, 2011, 330), while the proposal referring to the new Statute was negotiated in Madrid. Despite 
obtaining $74 \%$ of the vote in a referendum, participation was below $50 \%$, but maybe with the support of pro-independence and federalist parties, the Statute was approved.

2010 was the year when the Constitutional Tribunal ruled against the Statute, cutting most of its crucial articles. In July of the same year, the Catalan civil-society organization (Xarxa Òmnium) organized a demonstration under the slogan Som una nació, nosaltres decidim! (We are a nation and we have the right to decide!), which received the support of labour unions, many civic society organizations and political parties, with a turnout of more than a million people (BBC News, 2010). Even though in November of the same year CiU returned to power, in November 2012 the strongly pro-independence party Esquerra Republicana de Catalunya won the elections.

Since 2012 the idea of holding a referendum for independence has had a central place in Catalonia, with some parties in favour of it (Turp, Caspersen, Qvortrup, 2017, 12). It was the time when Assemblea Nacional Catalana (Catalan National Assembly) was created as an activist civil -society organization, whose purpose was the reaching of independence through democratic and peaceful means -; it was made of nearly 500 regional groups and played a key role in organizing the informal referendums. The first time when Catalan government tried to hold a formal referendum in order to become an independent republic took place in 2014, but it was blocked by law and declared as illegal by the Spanish government. Due to the provisions of the Constitution of Spain, which gave wide autonomy to the regions but affirmed the indissoluble unity of the Spanish nation. Instead of a referendum, Catalan president of that time -Arthur Mas- proposed a process of citizen participation, as an alternative to the referendum but the Spanish government announced that it would also block it. However, the Catalan government holded the "informal non-binding vote", in defiance of the Constitutional Court. This manifestation together with the major march which took place on 11 September (when Catalans are celebrating their national day) marked the initiation of the sovereignty process.

In 2013 the Parliament of Catalonia adopted by a large majority the "Declaration of Sovereignty and of the Right to Decide of the Catalan People", but in 2014 this act was declared by the Spanish Constitutional Court as being unconstitutional, and the Congress of Deputies rejected the authorisation of an independence referendum. Even so, the Generalitat began its own parallel consultation, which was, as expected, prohibited by the Constitutional Court (Boletín Oficial del Estado, 2014, 1-4). The 2015 Catalan regional elections were framed as a proxy for an independence referendum by the pro-independence parties; after an election campaign dominated by the independence issue, the results delivered a majority of seats in the Parliament but yet not a majority of votes (Marti, Cetrà, 2016, 107-119).

In 2016 Carles Puidgemont was elected as the Premier of the Generalitat, even if at that time he was a relatively obscure politician whose candidature had been promoted by hard-line supporters of the independence movement (Real Instituto Catalano, 2019, 22-26). Since that moment, the strategy to break with Spain was accelerated by the well-known self-determination referendum and the unilateral declaration of independence. The referendum took place in 2017, despite prohibitions by various courts and the day was dominated by the coercive action of riot police trying to prevent voting in some institutions. Pro-referendum posters widespread by more than 700 mayors were seized by the police, considered as illegal and criminal. The Spanish Government also threatened with the financial takeover of the Catalan budget (Baquero, 2018). The following days saw a strong reaction from the upholders of the Spanish Constitution who organised anti-independence protests in Barcelona; at this point the King Felipe VI of Spain gave a televised speech in which he accused the Generalitat of acting on the margins of the law and democracy (Holodny, 2017). In the same year, even so the political and social tensions were running high, the pro-independence groups in the Catalan parliament issued a unilateral declaration of independence with the support of just 70 of the 135 members of parliament, and so it had no impact and no international recognition. The same day, the Spanish 
STRATEGIES XXI International Scientific Conference

The Complex and Dynamic Nature of the Security Environment

Government triggered Article 155 of the Constitution, which assumed that if an Autonomous Community will not fulfil the obligations imposed upon it by the Constitution or other laws, there will be necessary the Spanish Government to step in self-rule, fully dissolving the Catalan Government and Madrid scheduling new regional elections (Agencia Estatal Boletín Oficial del Estado, 1978, 47). So it happened: the so-called "Spanish Constitutional Crisis" (known as the Catalan crisis) ended by invoking the article of Constitution that I've mentioned before. The Spanish government imposed direct rule over Catalonia, ending its autonomy and seizing control of the entire government institutions and infrastructure. Furthermore, the Spanish government began to prosecute a case against several of the autonomous region's leaders, as well as the organizers of the referendum. In the very next year, nine of the Catalan independence leaders were sentenced to prison.

In the spring of 2018 there was established a new government under the president Quim Torra - a pro-independence politician -. In 2019, the Barcelona-El Prat airport was forcibly closed because of the violent protests which took place; the reason was that the Spanish Court decided to send in prison several leaders of the independence movements which illegally unfolded two years before (Cordero, 2019). Regarding this, Torra called for an immediate halt to violence and suggested peaceful protests. Shortly thereafter, taking into account that violent protests branched out for many days, the Catalan president attempted to rally the crowd of protesters by stating that he would initiate a new independence referendum. Thus in October few minor trade unions linked to the pro-independence movement called for a general strike involving other violent clashes between masked protesters and police. After several days and nights of violence, Torra asked for talks between the Catalan independence movement and the Spanish Government, but the head of the Spanish government refused as he stated that it was impossible under Spanish law (Burgen, Jones, 2019).

The last two years came as a challenge for all countries around the world because of the emergence of Covid-19 as a global pandemic. But this fact didn't stop the Catalans from carrying out protests, at least on Catalonia's National Day. The 2020 Diada manifestation was a protest adapted to safety measures imposed by authorities due to the pandemic. Close to 60.000 people attended static protests across the region. In 2021, the Catalan National Assembly was the organizer of the event. It was estimated that over 400.000 people expressed their willingness to participate, but Barcelona's local police estimated the attendance at about 100.000. So the world crisis brought changes not only in health and economy but it also brought a "wave of calm" for the nationalist-separatists citizens of Catalonia, even if the relationship between Catalan Government and Spanish Government seem to endeavor in establishing a consensus regarding the statute of Catalonia.

\section{Opinions of several Catalonian citizens regarding the independence of their region}

As I said in the beginning of this paper, I initiated a survey containing 9 questions, which were physically handed over to a number of seventy citizens of Catalonia. Some of the questions had predefined answers, some of them required answers based on the considerations of the respondents. The language used to conduct the survey is Catalan, precisely to help respondents understand exactly what answers to give. The reason why I chose respondents from different fields of work is that I considered it would be a better way to find out if there are contrasts among their opinions. In this regard, taking into account the fact that in Catalonia there is currently a number of approximately 7.5 million inhabitants, the number of 70 chosen respondents represents $0.0009 \%$ of the total. Although the chosen sample does not represent a large enough part of the population to be able to form an exact opinion, they come from different backgrounds, live in distinct areas of Catalonia and have different social statuses. Of the total 
number of respondents, $45.71 \%$ are female, and the remaining 54,29\% are male. Also, the respondents can be divided into 4 categories, depending on their age: those aged between 18 and 25 are $25.71 \%$; those aged between $25-35$ are $45,72 \%$; in the category $35-55$ years are $22,85 \%$ of the sample; last but not least, those aged between 55 and 65 are $5.72 \%$. Regarding education, $97.14 \%$ attended at least high school education, $75.71 \%$ of respondents attended university, while only $47.14 \%$ did their masters or doctoral school.

At least, I divided the seventy respondents in five groups, based on their status of employment, as follows: unemployed citizens $-10 \%$ of the respondents - , employees in the field of agriculture $-11.43 \%$-, employees in the field of economy $-25.72 \%$-, employees in the field of public authorities $-37.14 \%$-, and employees in the legal field $-15.71 \%$. In the following I will describe my findings after collecting and analyzing all of the answers. This last division will be used as a general statistic to represent the answers to the nine questions.

For the first question "Do you consider yourself Spaniard or Catalan?", there are 2 answer options: 1. Catalans, 2. Spaniards. $68.57 \%$ of the respondents answered that they consider themselves Catalans and 31,43\% answered that they are Spaniards. According to gender, $42.86 \%$ of women and $57.14 \%$ consider themselves Catalan. Regarding the age criterion, the first answer was chosen as follows: $100 \%$ of the first age category; $87.5 \%$ of those aged between 25-35 years; $31.25 \%$ of those aged 35-55 years; $0 \%$ of those aged 55-65 years. As the results show, we can see that the young tend to support the nationalist-separatist principle more than the elderly. Is it a pure desire for separation or is it simply a faith they have acquired from those who campaign for independence? We can observe in Figure 1. the data sorted by their social status.

\begin{tabular}{|c|c|c|c|c|c|}
\hline Categories & Unemployed & Agriculture & Economy & $\begin{array}{c}\text { Public } \\
\text { Authorities }\end{array}$ & Legal field \\
\hline Answer 1 & $57,14 \%$ & $87,5 \%$ & $72,22 \%$ & $57,69 \%$ & $9,09 \%$ \\
\hline Answer 2 & $42,86 \%$ & $12,5 \%$ & $27,28 \%$ & $42,3 \%$ & $90,91 \%$ \\
\hline
\end{tabular}

Figure no. 1

There are two answers for the second question "Were you and your family born in Catalonia or another region?": 1. Catalonia, 2. Other regions. The percentages show that $77.14 \%$ of the respondents came from Catalonia and the rest of $22.85 \%$ belong to other regions like Castile de Leon, Galicia, Andalusia and Murcia. In the gender category, 57.40\% of women and $42.60 \%$ of men chose the first answer. Regarding the age, we can see that the rate of people aged between 18 and 35 born in Catalonia is much higher than people aged 35-65 years, as follows: for the age category 18-25 there is a percentage of 100\%; people aged between 25-35 are born in Catalonia in a proportion of $96.88 \%$; those in the age category $35-55$ are in proportion of $31.25 \%$, and the last age category has a percentage of $0 \%$. We can observe in Figure 2. the data sorted by their social status.

\begin{tabular}{|c|c|c|c|c|c|}
\hline Categories & Unemployed & Agriculture & Economy & $\begin{array}{c}\text { Public } \\
\text { Authorities }\end{array}$ & Legal field \\
\hline Answer 1 & $42,86 \%$ & $62,5 \%$ & $88,33 \%$ & $84,62 \%$ & $81,82 \%$ \\
\hline Answer 2 & $57,14 \%$ & $37,5 \%$ & $16,67 \%$ & $15.38 \%$ & $8,18 \%$ \\
\hline
\end{tabular}

Figure no. 2 
STRATEGIES XXI International Scientific Conference

The Complex and Dynamic Nature of the Security Environment

The third question "Have you participated in a public protest supporting the independence movement?" had two answer options: 1. Yes, 2. No. The answer revealed that only $25.71 \%$ of the respondents participated in an independence movement, while the rest of $74.29 \%$ didn't. A percentage of $21.88 \%$ of the total number of women respondents and $28.95 \%$ of the total number of men participated in a protest for independence. Regarding age, we can see that, young people tend to show greater support for pro-independence movements: $66.67 \%$ of young people aged 18-25 participated in public events; $27.78 \%$ of those aged between 25 35 years and only $5.56 \%$ of those aged between $35-55$ years; the last age group showed no interest in participating in the protests. I also think it is important to take a look at the percentages according to education: $50 \%$ of the people who chose the first answer attended at least high school; $44.44 \%$ attended university and in the category of those with postgraduate studies only $5.56 \%$ showed an interest in the independence movement. We can observe in Figure 3. the data sorted by their social status.

\begin{tabular}{|c|c|c|c|c|c|}
\hline Categories & Unemployed & Agriculture & Economy & $\begin{array}{c}\text { Public } \\
\text { Authorities }\end{array}$ & Legal field \\
\hline Answer 1 & $28,57 \%$ & $75 \%$ & $27,78 \%$ & $11,54 \%$ & $18,18 \%$ \\
\hline Answer 2 & $71,43 \%$ & $25 \%$ & $72,22 \%$ & $88,46 \%$ & $81,82 \%$ \\
\hline
\end{tabular}

Figure no. 3

On the fourth question "How do you think a pro-independence protest should unfold?" the respondents had to choose one of the following 3 answers: 1. Violent protests, 2. Pacifist protests, 3. Protests shouldn't exist. None of the respondents think that violent protests should exist. $63.64 \%$ of the respondents chose the second answer, $44.29 \%$ consider that these events shouldn't exist. The second answer was chosen as a percentage of $51.28 \%$ of the total number of women and $48.72 \%$ of the total number of men. The third answer was chosen by $38.70 \%$ of women and $61.30 \%$ of men. Regarding age, we can see that younger people show support in the existence of protests, while older people say they should not exist. Thus, the existence of protests is supported by $88.88 \%$ of those aged between 18-25 years, for the category 25-35 there is support in a percentage of $65.62 \%$ and from those aged between $35-55$ there is support in proportion of $12.5 \%$; the last age category does not consider the existence of protests necessary. A percentage of $11.11 \%$ of those aged between 18-25 opted for the third answer; $34.38 \%$ of those aged between $25-35 ; 87.5 \%$ of those aged $35-55 ; 100 \%$ of those aged $55-65$. The educational level shows that the support for protests is $98.47 \%$ for those who attended high school, $79.58 \%$ of those who attended university and $48.71 \%$ of those who did postgraduate studies. Those who claim that the protests should not exist attended $100 \%$ a high school, $70.96 \%$ a university and $45.16 \%$ postgraduate studies. We can observe in Figure 4 . the data sorted by their social status.

\begin{tabular}{|l|c|c|c|c|c|}
\hline Categories & Unemployed & Agriculture & Economy & $\begin{array}{c}\text { Public } \\
\text { Authorities }\end{array}$ & Legal field \\
\hline Answer 1 & $0 \%$ & $0 \%$ & $0 \%$ & $0 \%$ & $0 \%$ \\
\hline Answer 2 & $100 \%$ & $100 \%$ & $72,22 \%$ & $30,76 \%$ & $36,37 \%$ \\
\hline Answer 3 & $0 \%$ & $0 \%$ & $27,78 \%$ & $69,24 \%$ & $63,63 \%$ \\
\hline
\end{tabular}

Figure no. 4 
The fifth question "Do you agree with the independence movements of Catalans?" had two answer options: 1. Yes (plus a possible continuation of the answer), 2. No (plus a possible continuation of the answer). The percentage shows that $61,43 \%$ of the respondents agree with the independence movement. Few of their most common reasons to agree such a thing are: "Yes, because it is a very rich region that should not depend on a larger state.", "Yes, because I was born here and I see a bright future for such a developed region.", "Yes, because a large part of the area's revenues is taken over by the Spanish state.". Few of their common reasons to agree with the second answer option are "No, because it violates European standards.", "No, because the region could not govern itself.", "No, because such a small state does not have enough resources to support itself". In the gender category, the percentages show that $90.63 \%$ of women and $36.84 \%$ of men agree with the independence movement. Regarding age, we can see a decrease in support for pro-independence movements as they get older: in the first category of young people aged between $18-25,94.44 \%$ have a pro-independence attitude, those aged between $25-35$ in proportion of $59.37 \%$, those aged between 35-55 in proportion of $43.75 \%$ and the last age category is in total disagreement. It is interesting that out of the total number of people who support the demonstrations for independence, $100 \%$ attended a high school, $88.37 \%$ attended a university and only $27.90 \%$ of them also attended postgraduate studies; so, as the level of education increases, support for independence decreases. We can observe in Figure 5. the data sorted by their social status.

\begin{tabular}{|c|c|c|c|c|c|}
\hline Categories & Unemployed & Agriculture & Economy & $\begin{array}{c}\text { Public } \\
\text { Authorities }\end{array}$ & Legal field \\
\hline Answer 1 & $42,85 \%$ & $75 \%$ & $72,22 \%$ & $69,23 \%$ & $36,37 \%$ \\
\hline Answer 2 & $57,14 \%$ & $25 \%$ & $27,77 \%$ & $30,77 \%$ & $63,63 \%$ \\
\hline
\end{tabular}

Figure no. 5

For the sixth question "Do you agree with the fact that Spain does not approve independence?", there were two answer options: 1. Yes (plus a possible continuation of the answer), 2. No (plus a possible continuation of the answer). The results show a big percentage of agreement, $71.43 \% .18 .57 \%$ opted for the second answer. Few of the most common reasons to agree with the fact that Spain does not approve independence are:" Yes, because I agree with European values." or "Yes, because Spain does not have to divide.". Among their reasons to disagree, the most common are: "No, because they should also see the needs of the regions, not just those of the Spanish state." or "No, because in this way it violates the right to choose of the Catalan community.". The positive answer to this question seems to be the clear choice of older people. In this sense, it is necessary to observe the percentages for the first answer. $65.62 \%$ of the total number of women and $94.73 \%$ of the total number of men agree with the attitude of the Spanish government. The percentages in the age category show us that people aged between 18-25 years agree in a percentage of 50\%, those aged between 25-35 years are in percentage of $87.5 \%$ and people aged between 35-55, respectively 55-65 agree in proportion of $100 \%$. Regarding the level of education, $100 \%$ of those who chose the first answer have at least finished high school, $87.72 \%$ have completed university studies and $45.61 \%$ attended postgraduate studies. In Figure 6. we can observe the data sorted by their social status. 
STRATEGIES XXI International Scientific Conference

The Complex and Dynamic Nature of the Security Environment

\begin{tabular}{|c|c|c|c|c|c|}
\hline Categories & Unemployed & Agriculture & Economy & $\begin{array}{c}\text { Public } \\
\text { Authorities }\end{array}$ & Legal field \\
\hline Answer 1 & $71,43 \%$ & $50 \%$ & $77,78 \%$ & $88,46 \%$ & $90,91 \%$ \\
\hline Answer 2 & $28,57 \%$ & $50 \%$ & $22,22 \%$ & $11,54 \%$ & $9,09 \%$ \\
\hline
\end{tabular}

Figure no. 6

For the seventh question, "Do you think that Catalonia deserves independence?", there were two answer options: 1 . Yes (plus a possible continuation of the answer), 2. No (plus a possible continuation of the answer). The results show a small percentage of agreement, $24.59 \%$. and a big percentage of disagreement, $75.71 \%$. Through the most common arguments for the first question we can find: "Yes, because it has its own language and traditions.", or "Yes, because the struggle for independence has been a great desire of Catalans in recent decades.". For the second answer, the most common reasons to disagree with independence are: "No, because in this way the provisions of the Constitution would be violated." or "No, because there would be the possibility for the new state to enter into an economic collapse.". Women who chose the first answer are $18.75 \%$ and men are $28.96 \%$. The percentages according to age show us again an increased support for independence from young people, as follows: $72.22 \%$ of those who chose the first answer are people aged between 18-25 years, $12.5 \%$ are people with ages between 25-35 years, and the last two categories have a support percentage of 0\%. Respondents have the following levels of education: $94.12 \%$ attended high school and college, while only $17.45 \%$ attended postgraduate studies. In Figure 7 . we can observe the data sorted by their social status.

\begin{tabular}{|c|c|c|c|c|c|}
\hline Categories & Unemployed & Agriculture & Economy & $\begin{array}{c}\text { Public } \\
\text { Authorities }\end{array}$ & Legal field \\
\hline Answer 1 & $28,57 \%$ & $75 \%$ & $22,22 \%$ & $7,69 \%$ & $9,09 \%$ \\
\hline Answer 2 & $71,43 \%$ & $25 \%$ & $77,78 \%$ & $92,31 \%$ & $90,91 \%$ \\
\hline
\end{tabular}

Figure no. 7

For the eighth question "Do you think that Catalonia's independence can bring it a lasting development?" respondents had two answer options: 1. Yes (plus a possible continuation of the answer), 2. No (plus a possible continuation of the answer). The results show that only $15.71 \%$ of the seventy respondents opted for the first answer. The second answer was chosen in a proportion of $84.29 \%$. The most common reasons for choosing the first answer were: "Yes, because we have enough economic resources to ensure sustainable development." or "Yes, because our incomes based on agriculture are really big.". Through the most common arguments brought for the second option, we can find: "No, because even if the region has sufficient resources for development, it would be too difficult for our leaders to manage this." or "No, because if Catalonia gained independence, it would leave the European Union, so the economic system would have to be completely changed.". Although support for proindependence demonstrations appears to be significant (see answers to question 5), respondents to this question seem to be aware of the realities of the environment in which they live. Thus, in the gender category, only $9.36 \%$ of women and $21.05 \%$ of men believe that eventual independence could provide an environment which can lead to long-term development. According to the age criterion, 50\% of the respondents aged between 18 and 25 years, respectively $6.25 \%$ of the respondents aged between $25-35$ years chose the first answer; people 
aged between 35-55 and, respectively, 55-65 totally disagree with the idea that Catalonia would have a development if it separated from the Spanish kingdom. Also, the degree of education shows that $100 \%$ of the respondents who chose the first answer option attended at least one high school, $63.63 \%$ also attended university studies, and $36.36 \%$ attended postgraduate studies. In Figure 8. we can observe the data sorted by their social status.

\begin{tabular}{|c|c|c|c|c|c|}
\hline Categories & Unemployed & Agriculture & Economy & $\begin{array}{c}\text { Public } \\
\text { Authorities }\end{array}$ & Legal field \\
\hline Answer 1 & $42,85 \%$ & $37,5 \%$ & $16,66 \%$ & $3,85 \%$ & $9,09 \%$ \\
\hline Answer 2 & $57,14 \%$ & $62,5 \%$ & $83,33 \%$ & $96,15 \%$ & $90,91 \%$ \\
\hline
\end{tabular}

Figure no. 8

The last question was "Do you think that independence will one day become a reality?". The respondents had two answer options:1. Yes (plus a possible continuation of the answer), 2. No (plus a possible continuation of the answer). The results show that a very small part of the respondents believes in such a thing, $11.43 \%$. The rest of $88.57 \%$ opted for the answer "No". Among the most common arguments brought to the first answer, we can find: "Yes, because there is a strong Catalan spirit that fights for this ideal" or "Yes, because the protests will not stop until the independence goal is achieved". The most common reasons for choosing the second answer are: "No, because it violates European democratic standards." or "No, because the Spanish state would never accept this". It seems that the last question can give us a clearer picture of the respondents' opinions. Thus, in the gender category, 3.13\% of the total women and $18.42 \%$ of the total men consider that independence is an achievable aspect. In the age category we can see once again a greater support from young people than from older people: $33.33 \%$ of people aged between 18-25 and 5.56\% of people aged between 25-35 chose the first answer option; none of the respondents in the 35-55 or 55-65 age categories believe that independence is achievable. The level of education shows that $100 \%$ of the respondents who believe that independence can be obtained attended a high school, $87.5 \%$ attended university, but none of them attended postgraduate studies. In Figure 9. we can observe the data sorted by their social status.

\begin{tabular}{|c|c|c|c|c|c|}
\hline Categories & Unemployed & Agriculture & Economy & $\begin{array}{c}\text { Public } \\
\text { Authorities }\end{array}$ & Legal field \\
\hline Answer 1 & $28,57 \%$ & $25 \%$ & $16,67 \%$ & $3,85 \%$ & $0 \%$ \\
\hline Answer 2 & $71,43 \%$ & $75 \%$ & $83,33 \%$ & $96,15 \%$ & $100 \%$ \\
\hline
\end{tabular}

Figure no. 9

\section{Conclusions}

Following what is presented in this paper, it appears that the Catalan nationalistseparatists exist in several social categories, not only in the favoured or in the least favoured, from a social point of view.

From what I understand so far, the idea of autonomy was first introduced by political elites who saw potential in the geographical area of north-eastern Spain. Later, spreading this ideal among the citizens, they appropriated it and began to believe in a good organization of the region as a distinct part of Spain. However, Catalan citizens over the age of 35 understood, 
STRATEGIES XXI International Scientific Conference

The Complex and Dynamic Nature of the Security Environment

probably due to their experience in the environment in which they live, that Catalonia's independence would not be as constructive as it may sometimes seem. Even if there are still people in the population who have a high level of education and support independence, the percentage is too small to be taken into consideration. Linguistic and traditional differences have probably been a bonus for increasing autonomy support, but even if these differences exist, people with a sufficiently high level of education and work and social experience have become aware that they don't have enough arguments to separate a region from the rest of the state.

From the same perspective, we can look at the demand for independence, which was clearly not propagated for the first time by the citizens of Catalonia, but by its political leaders, who overestimated the capacity for development in the event of possible independence. The citizens welcomed with open arms the idea of possible independence, especially if we consider that it is a region that is distinguished from the rest of Spain by certain characteristics that have stood out throughout history. However, polls show that the ages of respondents who claim that the Catalan region should be independent are generally under 35, which leads me to believe that this nationalist-separatist spirit is rooted only in the minds of young people who have born at the end of the $20^{\text {th }}$ century or at the beginning of the contemporary era and that this ideal is spread only by those in this category precisely due to a lack of political and social experience.

In my opinion, mass protests and the use of illegal demonstrations or the use of violence began to develop when Spain used its organs of authority and the rule of law to stop growing support for independence. This shows us that, even in the $21^{\text {st }}$ century, some aspects of a political nature cannot be understood by all societies. First, the political elites who have supported independence since the beginning of the $21^{\text {st }}$ century tend to forget the exact provisions of the Constitution. Given that the population, in general, takes over political attitudes and behaviours induced by leaders and their ideals, some Catalan citizens have assimilated this desire for independence and turned it into an ideal they have shared with some political leaders. In fact, from my own research and discussions with people of Catalan nationality I have come to the conclusion that the youth category is most likely to act inappropriately in protests, just to draw more attention to the cause they support.

Personally, I consider the Catalan ideal to be unfeasible, given that the above surveys also show little support for the independence of the region. Even if some young people consider this to be something worth fighting for by any conventional or less conventional methods, their arguments are insufficient to make them a reality. I also believe that by re-establishing internal relations between Spain and Catalonia, communication between the two could lead to a consensus. Given that the Catalan region will be able to identify real reasons for achieving full independence, the Spanish Kingdom probably could not refuse its request. But given the lack of real reasons for demanding independence, it will remain an unfulfilled ideal, probably just like a simple thought in the memory of young Catalans.

\section{BIBLIOGRAPHY:}

Agencia Estatal Boletín Oficial del Estado. 1978. "The Spanish Constitution". UEL: https://www.boe.es/legislacion/documentos/ConstitucionINGLES.pdf

BAQUERO, S., Camilo. 2018. "New Catalan government sworn in, paving way for suspension of direct rule". URL: https://english.elpais.com/elpais/2018/06/02/inenglish/ 1527944812_829249.html

BEIZSLEY, Daniel. 2021. "Young Catalans wanted a country. They'll settle for a steady paycheck", accessed September 7, 2021. URL: https://www.politico.eu/article/spaincatalonia-independence-movement-youth-unemployment-identity-nationalism/ 
BURGEN, Stephen; JONES, Sam. 2019. "Catalan president calls for talks with Spain's government after unrest", accessed September 3, 2021. URL: https://www.theguardian.com/world/2019/oct/19/catalan-president-calls-for-talks-withspains-government-after-unrest-quim-torra

CARRERA, Xavier Vilà. 2014. "The domain of Spain: How Likely Is Catalan Independence?", Sage Publications, Inc. URL: http://www.jstor.org/stable/43555055

CONVERSI, Daniele. 1997. The Basques and Catalans and Spain: Alternative routes to nationalist mobilisation, London: Hurst

CORDERO, Dani. 2019. "Pro-independence protesters cause travel chaos at Barcelona airport", accessed September 5, 2021. URL: https://english.elpais.com/elpais/ 2019/10/15/inenglish/1571123222_635456.html

DE LA GRANJA Sainz, Luis, José; NOLLA Anguera, Pere; BERAMENDI G., Justo. 2001. "La España de los nacionalismos y las autonomías", accessed August 22 - 26, 2021. URL: https://dialnet.unirioja.es/servlet/libro?codigo=237385

Editors of ACN Barcelona. 2021. "Between 108,000 and 400,000 attendees in National Day pro-independence rally". URL: https://www.catalannews.com/politics/item/between108000-and-400000-attendees-in-national-day-pro-independence-rally

Editors of BBC News. 2010. "Catalan protesters rally for greater autonomy in Spain”. URL: https://www.bbc.com/news/10588494

Editors of Constitutional Court of Spain. 2014. "Constitutional Short Judgement 42/2014", accessed September 12, 2021. URL: https://www.tribunalconstitucional.es/Resoluciones Traducidas/STC\%2042-2014E(2)\%20\%20DECLARACION\%20SOBERANISTA\% 20\%20SIN\%20ANTECEDENTES.pdf

Editors of El Mundo. 2003. "Zapatero promete apoyar la reforma del Estatuto de Cataluña propuesta por Maragall", El Mundo. URL: https://www.elmundo.es/elmundo/2003/ 11/13/espana/1068756801.html

Editors of El País. 2005. "El Parlamento de Cataluña aprueba el nuevo Estatuto". URL: https://elpais.com/elpais/2005/09/30/actualidad/1128068217_850215.html

Editors of Encyclopedia Britannica. 2021. "Spanish Civil War", accessed August 7, 2021. URL: https://www.britannica.com/event/Spanish-Civil-War

Editors of GenCat, n.d. 2021. "The contemporary Government of Catalonia (20th and 21st centuries". URL: https://web.gencat.cat/en/generalitat/historia/generalitatcontemporania/

Editors of GenCat, n.d., "Catalan language". URL: https://llengua.gencat.cat/en/elcatala/origens-i-historia/

Editors of Madrid Embassy, n.d. 2021. "Kingdom of Spain. General Information”. URL: https://madrid.embassy.qa/en/kingdom-of-spain/info

Editors of Real Instituto Elcano. 2019. "The independence conflict in Catalonia". URL: http://www.realinstitutoelcano.org/wps/wcm/connect/d8496562-e096-44a1-81dab871c91ccf62/Catalonia-dossier-elcano-october-2019.pdf?MOD=AJPERES\& CACHEID=d8496562-e096-44a1-81da-b871c91ccf62

Editors of Statistical Institute of Catalonia. 2020. "Total and foreign population series". URL: https://www.idescat.cat/poblacioestrangera/?b=0\&lang=en

FERNANDEZ MORENO, Luis. 1986. Decentralization in Britain and Spain: The cases of Scotland and Catalonia, University of Edinburgh. 
FERREIRA, Carles. 2021. "Entrapped in a failing course of action: Explaining the territorial crisis in 2017 Catalonia". URL: https:/www.tandfonline.com/doi/full/ 10.1080/13597566.2021.1907570

FOGUET I BORREU, Francesc. 1966. Història de la premsa catalana (1966). Barcelona: Universitat Autònoma de Barcelona.

HENDERS, J. Susan. 2010. Territoriality, Asymmetry and Autonomy: Catalonia, Corsica, Hong Kong and Tibet, United States, Palgrave Macmillan.

HOLODNY, Elena. 2017. "Catalan authorities «have placed themselves outside the law and democracy»". URL: https://www.businessinsider.com/spanish-king-on-cataloniareferendum-in-rare-tv-address-2017-10

KEATING, Michael. 1994. "Naciones, nacionalismos y estados.". Revista internacional de filosofía política. URL: https://dialnet.unirioja.es/servlet/articulo?codigo=2704608

MARTI, David; CETRÀ, Daniel. 2016. "The 2015 Catalan election: a de facto referendum on independence?". URL: https://www.tandfonline.com/doi/abs/10.1080/13597566. 2016.1145116? journalCode $=$ frfs20

RIOS, Pere; BAQUERO, S., Camilo. 2019. "Catalan leader condemns violence, calls for meeting with Spain's PM". URL: https://english.elpais.com/elpais/2019/ 10/22/inenglish/1571754336_234078.html

SOLIS, Fernando, Leon. 2003. Negotiating Spain and Catalonia Competing Narratives of National Identity, Bristol, UK: Paperback.

TURP, Daniel; CASPERSEN, Nina; QVORTRUP, Matt; WELP, Yanina. 2017. "The Catalan Independence referendum: An assessment of the process of self-determination". URL: https://www.researchgate.net/publication/321934266_The_Catalan_Independence_refer endum_An_assessment_of_the_process_of_self-determination

VILAREGUT, Sáez, Ricard. 2011. "Memory and emergency in Catalan independence. The case of the Platform for the Right to Decide". URL: https://ca.freejournal.org/ 89952/1/plataforma-pel-dret-de-decidir.html 